Meltem

Journal of the Izmir Mediterranean Academy

No. 2, Winter 2017, 91-96, DOI 10.32325/iaad.2017.33

\title{
An Interview with Polly Pallister-Wilkins: Mediterranean as a Humanitarian Border
}

\section{Zeynep Gönen}

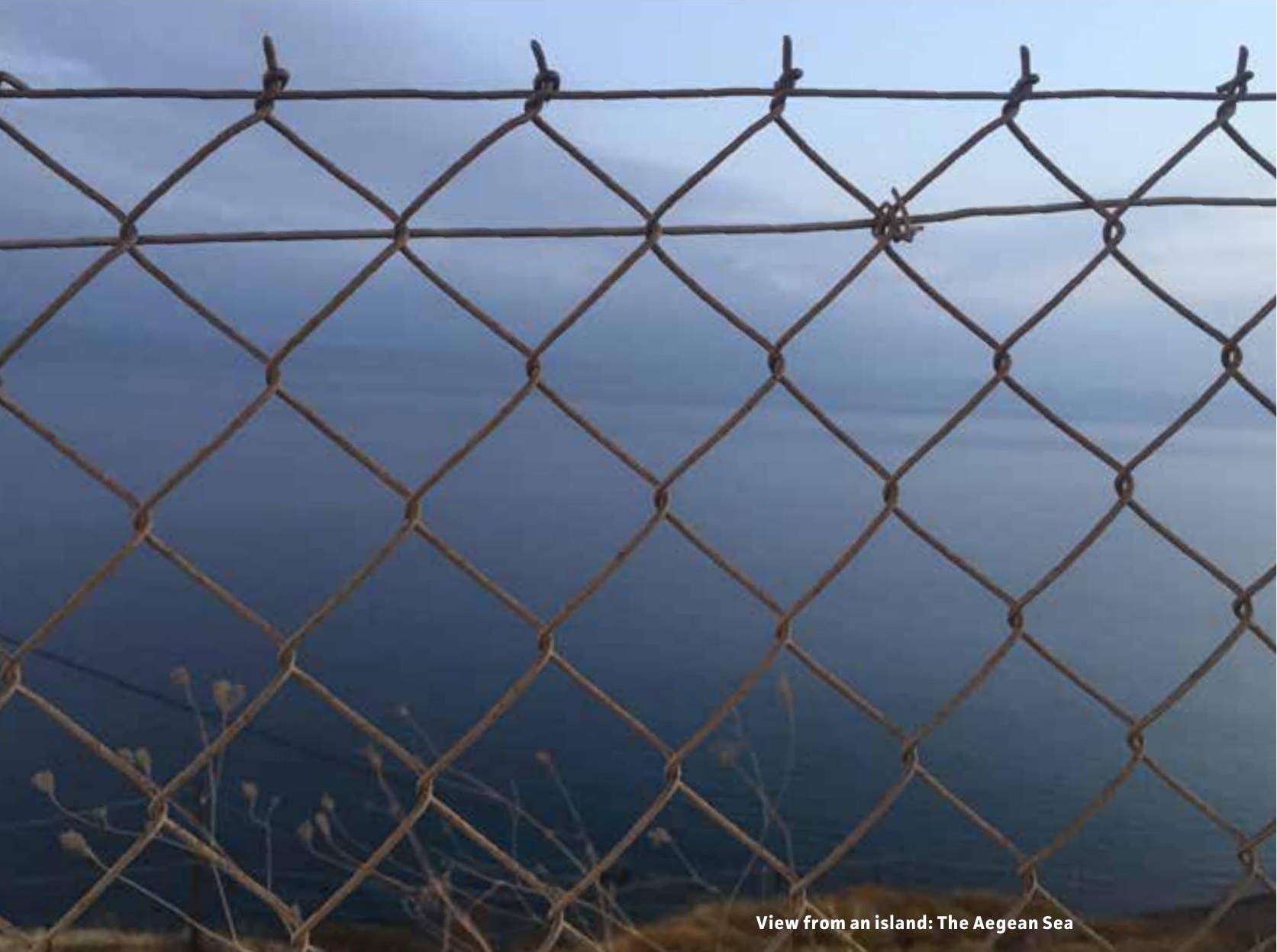

Polly Pallister-Wilkins works in the Political Science Department at the University of Amsterdam, the Netherlands. Her current research is concerned with humanitarian border policing practices in Europe. She was in the field during the recent refugee crisis in the Mediterranean.

Meltem tries to understand what "Mediterranean" is, and how this geography is changing and is being shaped. It seems that one of the central issues shaping the Mediterranean today is about migration and security, about movements of people, and expansion of borders. In your work, you explore these issues especially with respect to the border practices and their meaning. First of all, can you explain the actual dynamics and history of migration and borders in the Mediterranean?

This is a question that cannot possibly be answered in a short way. In terms of the history of 
borders, bordering and migration in the Mediterranean, how far back in history do we go? To the Phoenicians? The Greeks? The Roman Empire or do we go even earlier? The Mediterranean has always been a place of mobility, of interconnection as Braudel made so clear in his work. Its name tells its story in this regard. But of course, it has also been a place of separation too and this has seemingly accelerated over the previous decades.

Some of the countries that border the Mediterranean have become some of the most "bordered" in the world. Israel's occupation of Palestine has led to practices of separation not seen anywhere else and are at the forefront of the logics and technologies used to enforce separation and restricted movement between states but also at a more local level. These logics and technologies are being exported around the world, to other Middle Eastern countries, to South and Southeast Asia, Europe, North and South America, Australasia, Africa...

Over the last two-three decades the Mediterranean has become a very insecure, dangerous and exclusive space through European involvement in hardening the external borders and the denial of safe and legal forms of travel to Europe to the majority of the world's population. Interconnections are being reshaped along axes of wealth and privilege and of course this interconnects with race. So also we have colonialism's legacy playing a role and eliding with dynamics of neoliberal capitalism generating mobility and migration and creating a system of both increasing mobility and increasing closure. These forces come together in the Mediterranean and other places around the world such as the US/Mexico border.

\section{Bordering practices exist to try and govern mobility just as much as they exist to de- marcate territory.}

Who are the different actors, and what are the different practices shaping the Mediterranean as a borderland?

Again, this is a question without an easy answer. Migrants are a key actor. Mobile people. States are another main actor and not just European states. This is not a one way, Eurocentric process only. Private actors, corporations with an interest in security technologies; smugglers, who are facilitating the mobility of those migrants denied regular and safe forms of transportation, all of these actors shape the Mediterranean as a borderland. Then of course there are also those countries/societies that have produced large migrant/refugee populations. They are also shaping the Mediterranean as a migratory space. So, the various actors in Syria and Iraq, and further east in Afghanistan, also Libya and the different factions there, Eritrea and on and on it goes. They all work to shape the Mediterranean. You start to see how this is not an easy question with an easy answer and I haven't even talked about the types of bordering practices that we can find in the Mediterranean.

In terms of practices, we see many different practices, firstly and perhaps the most important is mobility itself. Mobility and borders cannot be separated out. Bordering practices exist to try and govern mobility just as much as they exist to demarcate territory. So, there are many different practices that exist to govern mobility in the Mediterranean but these are not only located in the Mediterranean. They are global. They are, for example, the Nigerian woman denied a visa to travel to the EU in an embassy in Lagos because she doesn't have savings of $€ 10,000$, or the Afghani student denied a visa to travel to the EU to study because he doesn't have a birth certificate.

In connection with the first question, you researched and wrote about Frontex, as one of the most central actors in the Mediterranean. Can you explain what this institution is, and why it is important for understanding the Mediterranean?

I don't think I have ever explicitly said that Frontex is one of the most central actors in the Mediterranean. It is one actor. To say it is one of the most central actors masks many things and gives a false picture. There is a lazy stereotype that has become popular that "Frontex Kills," this goes along with the idea that Frontex is one of the most central actors. To see it as one of the most 


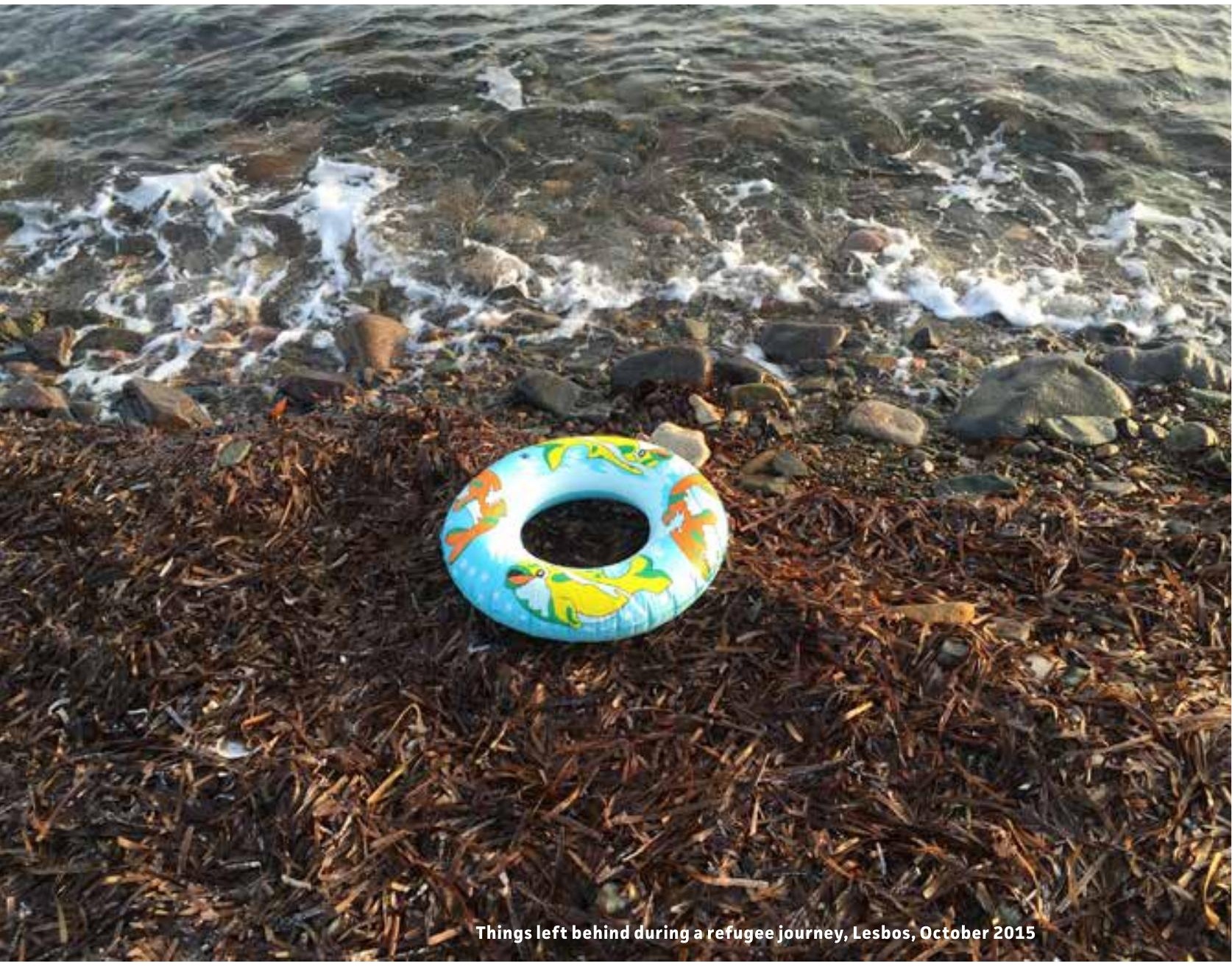

central actors is to buy into the technocratic logics of the European Union that works to render invisible political decisions and political responsibility.

If by Frontex you mean the European Union and its member states, therefore, "Europe" more generally, then yes, we can say that currently Europe is an important actor in shaping the Mediterranean as an exclusive space of mobility. Frontex is only the coordinating body of the European Union in charge of overseeing member state policing of the external borders. Frontex now stands for "The European Border and Coast Guard Agency" and took its name from the French Frontières extérieures of its old name: the "European Agency for the Management of Operational Cooperation at the External Borders".

The words management and operational cooperation are important here. It shows the technocratic nature of Frontex. We need to go beyond this. Frontex does not actually have much power. It can work to set-up and assist joint-operations in particular border spaces but these are always "joint" carried out with member states. It helps to pool resources of member states to address particular border "crises" but it does not act on its own. It has no sovereignty, no power of arrest or detention or expulsion. This is really important to understand because the phrase "Frontex Kills" alongside Frontex being presented as a central actor is misleading and I would 
say politically dangerous as it allows Europeans and others to find a scapegoat for the border violence that we see. It allows European Union citizens to place the blame on a technocratic body rather than recognise that the border policies of the European Union come from the politicians, the European Council, politicians that we vote for, representatives from our member states. These policies are devised and supported by our democracies. We see support for them everyday in our media and the practices they engender are carried out by our own security forces, be they border police, immigration officials etc. This is an Italian issue, a Spanish issue, a Greek issue, a German issue, a French issue, a Dutch issue, a Polish issue, a Swedish issue etc. All of these states, all 28 member states, their governments and their electorates are responsible for these policies. Frontex is only one technocratic and front-line actor in a much large machine. Frontex does not make the policies, Frontex did not decide that the majority of the world's population would be denied access to air travel into the EU without the correct visas for example. That was politicians from European member states. Frontex did not devise practices of externalization that was member states such as Italy but also proposed by the UK, by the Netherlands etc. Frontex did not devise large-scale surveillance practices designed to intercept, capture and keep-out migrants. These were already being done by member states such as Spain with its SIVE system.

\section{I am writing this sitting on a veranda overlooking the Mediterranean, in Hamra Beirut. There's lots of leisure happening on the Corniche down below me. But of course, Bei- rut has also been a very violent place.}

Why did the Mediterranean become so violent? Which practices or larger structures we should be looking at in understanding the Mediterranean as a dangerous place rather than a place of leisure, as it used to be associated with?

Firstly, the idea that there was a before time of non-violence and a now time of violence is too simplistic. The Mediterranean may have been a place of holidays and sunshine, and it still is for many people. I am writing this sitting on a veranda overlooking the Mediterranean, in Hamra Beirut. There's lots of leisure happening on the Corniche down below me. But of course, Beirut has also been a very violent place. The Mediterranean has also been a very violent place historically, as much as it has a history of interconnection. It is and was also a place of violent conquest, battles, wars going back centuries. The history of the Mediterranean is as much a history of violence as it is one of interconnection. I think it is important to keep this in mind; these things co-exist simultaneously.

In terms of the loss of life we have been seeing in the Mediterranean over the last two-three decades and that has escalated due to increased political violence in the last seven years or so, this can be linked to the restrictive and exclusive border practices of the European Union that denies access to safe and legal routes for people fleeing, violence in all its forms: conflict, oppression, poverty...

\section{How does securitization contribute to insecurity and violence in the Mediterranean?}

If by insecurity and violence you mean border insecurity and border violence, this is done through denying people access to safe and legal forms of travel. This in fact also contributes to other forms of insecurity and violence as it creates a possibility for smuggling and organized crime to take advantage that in turn fuels certain actors such as the militias in Libya. Safe and legal routes have been systematically closed off to non-Europeans, or the non-privileged, due to the belief that migrants are dangerous and a security threat which is only a correlation and also because Europe wants to prevent migrants seeking employment in Europe while enjoying a quality of life that is fuelled and made possible by irregular, precarious labour. Securitization has created a perfect storm, where those seeking exclusivity based on racism and a false belief in the threat posed by others (that usefully allows Europe to think the problem is out there rather than within), and at the same time to benefit neoliberal capital by providing pools of irregular labour that can be exploited and profited from. 


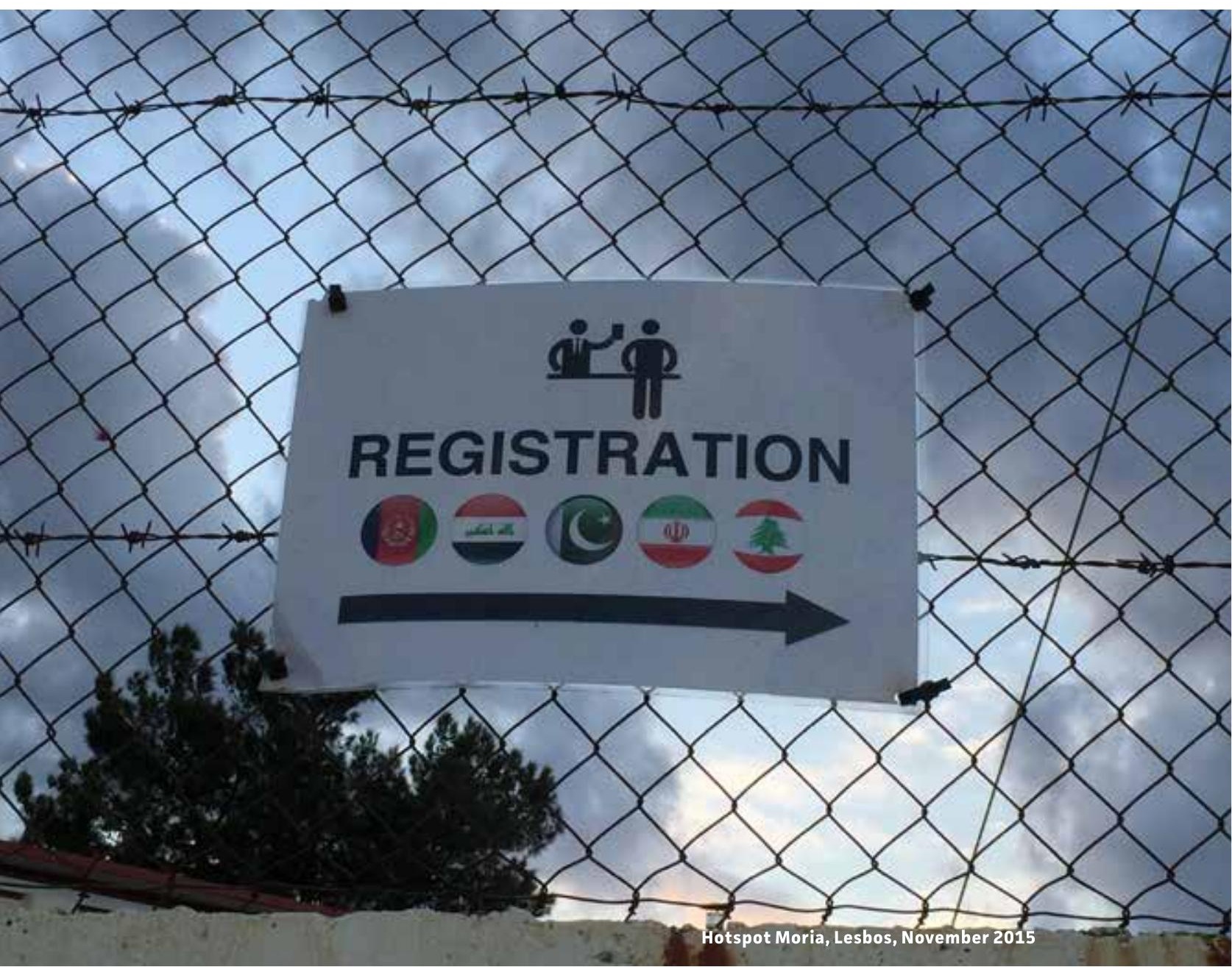

You suggest that the Mediterranean is also being constituted as an "humanitarian border". What do you mean by "humanitarian border"? How is it different than "borders" as we know it? How do the Mediterranean border agencies control migration through policing and engage in "humanitarian" action at the same time?

A humanitarian border is the result of an unequal and violent border. The humanitarian border grows from an unequal and violent border. As mobility and the crossing of borders have become more and more restricted, it has become more dangerous as it leads to people to use smugglers and to travel irregularly. Of course, geography is important here. The sea adds increased risks to those travelling irregularly. All of this results in life saving interventions occurring in border spaces. These are humanitarian interventions, designed to save lives in that instance. The humanitarian border would not and should not exist. It exists because of the structural inequalities of borders today. Humanitarianism more broadly is always a conservative response to problems caused by political structures and failures. Humanitarianism allows intervention to save lives without addressing the underlying structural and political causes.

As for how a humanitarian border is different from more "traditional" borders. That depends on what people already understand the border as. Borders have always had a security element 
to them. They are supposed to keep the population safe from attack from "others". The difference with humanitarian borders today is that those being saved are not citizens but the "others", the excluded rather than the included. So, what we now see at the humanitarian border is that the migrant is both the traditional "other", the excluded "other", so a risk, but also because of the violence of borders today migrants are also at risk.

In terms of how actors in the Mediterranean engage in both caring and controlling at the same time, this happens very easily. A police person's role is that of care and control. They are meant to secure life and uphold law and order. There is no immediate, a priori contradiction here. The contradiction often comes in their everyday working lives when border police rescue people and then deport them. But in many instances the saving of live enhances border control as it expands the space and time of intervention. For example, the SAR zone in the Mediterranean is a much larger space for intervention than the border-policing zone. Saving lives means that border policing operatives can intercept migrants much earlier and over a much larger geographic space.

Humanitarianism is a security practice. It is about providing the necessary conditions for life. States provide security for their populations through providing the necessary conditions for life.

In your work, you connect the logics of humanitarianism with that of security. Can you elaborate on this connection? How can we understand policing that seeks to capture "illegal" flows of people in the Mediterranean, and the rescue practices of different actors in the Mediterranean?

Humanitarianism is a security practice. It is about providing the necessary conditions for life. This is security. States provide security for their populations through providing the necessary conditions for life. Humanitarianism is the provision of the necessary conditions for life universally, based on a belief in the universality of humanity, so beyond particular populations based on citizenship or territory. The humanitarian subject is the suffering subject.

Policing is also about care for life as well as control and upholding the rule of law. In fact, the rule of law is part of providing the necessary conditions for life. The idea of care and control as two separate logics is false. Therefore policing in the Mediterranean have always involved, at least from the European perspective, with the various agencies involved simultaneous elements of care and control. Border police have a responsibility to police the border but they also have a responsibility to police life that is to care for life. What has happened in the Mediterranean but elsewhere too is the use of this policing of life to expand the policing of borders both temporally and spatially.

In understanding the contemporary states around the globe and migration, what insights does the Mediterranean offer?

I think the Mediterranean offers a view of the increasing violence of borders more generally. However, the Mediterranean is not unique. We see similar practices in Australia, with externalization and gross human rights abuses. The Mediterranean allows us to see how humanitarianism with its logic of care as opposed to emancipation continues to be used for the purposes of controlling "others" in similar ways to how it was used during European colonialism. As well as humanitarianism, the Mediterranean is a laboratory for a range logics and techniques for the expansion and deepening of sovereignty across time and space, beyond the line of state borders both externally but also internally. We see how sovereignty is consolidating itself in the face of increased global mobility. But we also see how mobile subjects refuse to be controlled and find ways to demand and achieve their rights to mobility or immobility and secure futures. 